\title{
Document Management System
}

National Cancer Institute

\section{Source}

National Cancer Institute. Document Management System. NCI Thesaurus. Code C54636.

A computer program (or set of programs) used to track and store images of paper documents. Document management systems commonly provide check-in, check-out, storage and retrieval of electronic documents often in the form of word processor files and the like. 